határozta meg Baranya megyében a földrajzi tájkörzetek függvényében.

Bács-Kiskun megye homoki tanyás községe - Jakabszáliás - szakszövetkezetével kapcsolatosan két kutató is végzett eltérô szempontú vizsgálatokat. Kovács T. a helyi Népfront Szakszövetkezet kialakulásáról és fejlődéséről ad történeti áttekintést, kiemelve az emberi tényezó, a helyi yezetés személyi feltételeinek szerepét e folyamatban. Gurzó I. pedig a szakszövetkezet termelési szerkezetét és termékforgalmi kapcsolatainak alakulását tárta fel a 80 -as évek elsố felében, utalva ezek jövöbeni várható változásaira is.

A néhány oldalas 9. tanulmány két alföldi kutató - Tímár J. és Simon I. - kutatási koncepcióját ismerteti és részeredményeket közöl a két Békés megyei telepưlésen - Ujkígyóson és Szabadkígyóson - végzett felmérésekról. A két település reális társadalomföldrajzi képének és kapcsolataik területi rendszerenek megrajzolásához a kutatások folytatása szükséges.

Az első tanulmányt kivéve, mindegyiket értékes információkat tartalmazó térképek, diagramok, kartogramok, táblázatok teszik még teljesebbé.

Ugyancsak jelentôs terjedelmú a kötetben a „Kilátó” c. rovat, melyhez Berényi I. írt bevezetőt, mivel ez a rész a szociálgeográfia egyik ága - mely a Müncheni Iskola néven vált ismertté - képviselőinek a III. Bajor-Magyar Szemináriumon elhangzott előadásait tartalmazza. A 7 elŏadás mindegyike München és/vagy térsége térszerkezeti átalakulásának legújabb jelenségeivel foglalkozik. Közülük az egyik legérdekesebb Karl Ruppert értekezése, amely a müncheni körzet változó térszervezödést mutatja be a város és város környéke viszonyának átalakulásán keresztül. Ismerteti a gócváros és környéke közötti népességmozgásnak és az ipartelepítésnek a fejlődési tendenciáit, utalva az ezekböl fakadó problémákra, konfliktusokra. Végezetül pedig felhívja a területfejlesztési politika képviselöinek figyelmét arra, hogy a kialakuló új térszerkezetet a jövőben nem szabad figyelmen kívül hagyni.

A Területi kutatások 8. száma további kisebb terjedelmú rovatai közül csak a „Profil” c. rovat ér demel említést, amely ben Kovács $Z$. egy fiatal, kütföldön is ismert és elismeri lengyel kutatót mutat be. Zbigniew Rykiel pályájának fóbb állomásai után az egyik nagy jelentōségû́ tanulmány részfejezetét is elolvashatjuk, mely ,... a határhatás mechanizmusnak a társadalmi-gazdasági fejlődésben játszott szerepével..." foglalkozik.

Úgy gondolom, hogy e kötet megjelenése is hozzájárul egy nálunk még alig ismert és csak kevesek által müvelt tudományág - a szociálgeográfia - alaposabb megismeréséhez és „népszerüsítéséhez". A témák sokszinüsége, rendkivüli gazdagsága pedig lehetôvé teszi - a szociálgeográfia sokoldalúsága bemutatásán kívül azt is, hogy a kötetben mindenki (szakember és nem szakember) megtalálja a számảra leginkább érdekes fejezeteket.

KISS ÉVA

\title{
ÖSTERREICHS STÄTDTE UND MÄRKTE IN IHRER GESCHICHTE OSZTRÁK VÁROSOK ÉS MEZŐVÁROSOK TÖRTÉNELMÜKBEN
}

\author{
(Bécs, 1985, 151.p.)
}

Az osztrák várostörténeti irodalomnak értékes gyöngyszeme ez a könyv, amely Erich Zöllner előszavával és kiadásában jelent meg. Az előszóban $E$. Zöllner jelzi, hogy e kötet célja annak bemutatása, hogy a városok hely. zetében ma megmutatkozó problé mák gyökerei milyen mélyre nyúlnak. A problémák múltját kívánják feltárni, hogy ezzel a jelenben fellen- dült várostörténeti kutatások számára is eligazítást adjanak.

A kötet tanulmányainak témái - e célkitüzésnek megfelelően - több évszázadot ívelnek át. Az első tanulmány (G. Langmann római kori régészprofesszor tollából) az Ausztria területén található római városok történetét tekinti át, majd $F$. $O p l$ bécsi levéltáros a városalapítás 
és várossá válás történeti kérdéseirōl ad képet a korai középkorból. Érdekes megállapítása, hogy pl. Bécs várossá alakulásában a római múlt s a hercegi politika városteremtő törekvése is belejátszott. Ezt egészíti ki $K$. Lohrmann tanulmánya: „Észrevételek a városi lét kérdéseihez Ausztriában" címmel. Ez az értekezés - a várostörténeti irodalom rövid birálatán túl - a későközépkori városfejlődés néhány fontos $\mathrm{moz}$ zanatát (áruelosztási problémák, központi helyek kialakulása, a városok közti versengéssel kapcsolatos hercegi politika, a városok nemzetközi hatásköre stb.) emeli ki.

$H$. Knittler az osztrák városok korai újkori helyzetét tekintette át, a XVI. és XVII. századra vonatkozóan folytatva vizsgálatait. Négy problémakört emelt kj:

1. a város és a piac körzetének kiépülését (számszerúen),

2. a városi népesség nagyságát és a városok tipusait,

3. a városokkal kapcsolatos rendelkezéseket és az alkotmányos fejlődést, $s$ végül

4. a városi társadalomszerkezet elemzésének problémakörét.

E tanulmányban már említést nyernek azok a legfontosabb várostípusok, amelyek Ausztriában fellelhetôk (bányász, ipari, kereskedelmi, agrár jellegü, rezidencia városok stb.), amelyeket a ,nagy Ausztria" távolabbi területein található városokkal is összehasonlít (pl. Érsekújvár, Karlovác, Tirol városaival).

A következó tanulmány időben elörehaladva $F$. Mathis: Városok és mezóvárosok a korai indusztralizáció idején címmel Mária Teréziától a reformkorig, lényegében a XIX. század közepéig vizsgálja az osztrák városfejlődést. Megállapítása szerint a felvilágosult abszolutizmus centralizációs és egyesítési törekvései folytán a városok addigi kiváltságos, söt kiemelt helyzete megváltozott. Gazdálkodásukat állami felügyelet alá helyezték, sốt II. József még a városi magisztrátus szerikezetét is módosította. Városi elôjogok és bevételi források szüntek meg, miáltal egyes városok nanyatlani kezdtek. Érdekes jelenségnek tekinthető Ausztriában, hogy a korai indusztralizáció kezdeményezói nem a városok voltak, hanem egyes feudális (?) nagybirtokok.

Itt jegyzem meg, hogy hazánkban is egyes ipari üzemek nagybirtokokon és nagybirtokosok kezdeményezésére jöttek létre. De ebben a folyamatban nem e latifundiumok feudális eredete és esetleg azokban még megtalálható feu- dális eredetü maradványok, hanem éppen az árutermelésre és értékesítésre való törekvés, tehát azok kapitalizálódása játszott szerepet! Ebben $\mathrm{az}$ időszakban váltotta fel a városi polgár fogalmát az állampolgáré és ez nyilván mélyebb változásokat takart.

E kötet egyik legérdekesebb tanulmảnya E. Deák kvantitatív vizsgálata, a mellyel a városi fejlödést Ferenc József hosszú uralkodása idején kivánta áttekinteni. Ennek a szabadságharctól az első világháború derekáig terjedő időszaknak városi fejlôdése - a számítógépes feldolgozás és analízis szerint - két vágányon haladt. Egyrészt megindult és kialakult az az urbanizációs folyamat, amelynek egyik fó jellemzóje a városokba vándorlás volt. Másrészt megfigyelhető egy polgárosodási folyamat. A városi életforma kialakulása az 1910-es évekre tehető, de korán tsem szakadt meg az első világháború befejezôdésévei, hanem folytatódott tovább.

W. Rausch professzor tanulmánya Ausztria városairól az elsô köztársaságtól a másodikig - időben ennek folytatása. Az első világháború utáni városok problémái közül első helyre a tuberkulózis elleni küzdelmet teszi, majd a munkanélküliség pusztítását említi. Vázolja a világválságot követő nyomasz tó helyzetet $s$ ismerteti azt a politikát, mely az Anschlusshoz vezetett, s Ausztriát a német birodalom Ostmarktjává süllyesztette. Az a látszat, amely ezt követően a gazdasági élet javulását mutatja, szoros összefüggés ben állott Hitlerék külpolitikájával, és végeredményben éppen a városokat sujtotta legjobban (bombázásokkal, egyéb háborús pusztításokkal).

H. Kühnel tanulmánya már egy, közvetlenül a mai városi életet érintő problémakörrel foglalkozik, történeti aspektusból. A szanálás, a múemlékvédelem, az újjáépítés kérdéseit tekinti át Ausztria városaiban. E téma tör ténetéhez tartozik a középkor szép építményeinek megörzését hangoztató hajdani politikai vezetôk és mưvészek állásfoglalása, akik a régi értékek elpusztítása nélkül kívánták az újabb kor által megkivánt kényelmet megteremteni. 1973ban Bécs egyes történeti épületeit magában foglaló részeit "védelmi zónákká" nyilvánították, és olyan akciót indítottak, amely az osztrák városok egész sorának vezetôségét müemlékvédelmi intézkedések megtételére késztette. Ovni kezdték a régi városképet, sürgették a ,revitalizálást", mely a müemlék belső modernizálásával és küisejének konzerválásával óvja a patinás vảrosképet. 
A kötet utolsó tanulmánya $R$. BanikSchweitzer mérnök tollából született, aki a várostervezés legfontosabb feladatait tekintette át Ausztriában. A mérnöki alapossággal és közgazdász elemzéssel készült értekezés igen kritikusan vizsgálta meg a mai Bécs külső átalakulásával kapcsolatos építészeti és egyẻb problémákat : az erős beépítettséget, a városon kívüli területek fejlesztésének nehézségeit, a város szélén történt magas építkezéseket, a slumosodás veszélyét stb. Tanulságként azt vonja le, hogy a hagyományos várostervezés a maga speciális kelléktárával keveset érhet el e problémák megoldásában. Ahhoz azonban, hogy szélesebb tömegek direkt részvételét tartósan lehessen biztosí- tani a városi építkezésekkel kapcsolatos döntéshozatalokban ",társadalmi struktúra változásra van szükség, amely messze túlmutat a polgári iniciativák reformpotenciálján".

A sokszínú kötet minden egyes, különböző korok szakertôi és különböző foglalkozású, főhivatású szerzooi által írt tanulmánya egy célt szolgál: a mai problémák gyökereit keresi a múltban, e problémák megoldására tesz kísérletet. A nemcsak Ausztrában, hanem hazánkban is fellendülő várostörténeti kutatások számára az ilyen „hosszú távú”, sok tudomány oldaláról történő elmélyült elemzése knek vitathatatlanul nagy a tudományos, és remélhetóleg hamarosan a ,gyakorlatba" is átszivárgó haszna és értéke. 